\title{
Mercury methylation in paddy soil: source and distribution of mercury species at a Hg mining area, Guizhou Province, China
}

\author{
Lei Zhao ${ }^{1,2}$, Christopher W. N Anderson ${ }^{3}$, Guangle Qiu ${ }^{2}$, Bo Meng ${ }^{2}$, Dingyong Wang ${ }^{1}$, and Xinbin Feng ${ }^{2}$ \\ ${ }^{1}$ College of Resources and Environment, Southwest University, 400716 Chongqing, P.R. China \\ ${ }^{2}$ State Key Laboratory of Environmental Geochemistry, Institute of Geochemistry, Chinese Academy of \\ Sciences, 550002 Guiyang, P.R. China \\ ${ }^{3}$ Soil and Earth Sciences, Institute of Agriculture and Environment, Massey University, Palmerston North, \\ New Zealand
}

Correspondence to: X. B. Feng (fengxinbin@vip.skleg.cn) and B. Meng (mengbo@vip.skleg.cn)

Received: 13 December 2015 - Published in Biogeosciences Discuss.: 27 January 2016

Revised: 18 April 2016 - Accepted: 19 April 2016 - Published: 27 April 2016

\begin{abstract}
Rice paddy plantation is the dominant agricultural land use throughout Asia. Rice paddy fields have been identified as important sites for methylmercury ( $\mathrm{MeHg}$ ) production in the terrestrial ecosystem and a primary pathway of $\mathrm{MeHg}$ exposure to humans in mercury $(\mathrm{Hg})$ mining areas. We compared the source and distribution of $\mathrm{Hg}$ species in different compartments of the rice paddy during a complete ricegrowing season at two different typical $\mathrm{Hg}$-contaminated mining sites in Guizhou province, China: an abandoned site with a high $\mathrm{Hg}$ concentration in soil but a low concentration in the atmosphere and a current-day artisanal site with a low concentration in soil but a high concentration in the atmosphere. Our results showed that the flux of new $\mathrm{Hg}$ to the ecosystem from irrigation and atmospheric deposition was insignificant relative to the pool of old $\mathrm{Hg}$ in soil; the dominant source of $\mathrm{MeHg}$ to paddy soil is in situ methylation of inorganic $\mathrm{Hg}(\mathrm{IHg})$. Elevated $\mathrm{MeHg}$ concentrations and the high proportion of $\mathrm{Hg}$ as $\mathrm{MeHg}$ in paddy water and the surface soil layer at the artisanal site demonstrated active $\mathrm{Hg}$ methylation at this site only. We propose that the in situ production of $\mathrm{MeHg}$ in paddy water and surface soil is dependent on elevated $\mathrm{Hg}$ in the atmosphere and the consequential deposition of new $\mathrm{Hg}$ into a low-pH anoxic geochemical system. The absence of depth-dependent variability in the $\mathrm{MeHg}$ concentration in soil cores collected from the abandoned $\mathrm{Hg}$ mining site, consistent with the low concentration of $\mathrm{Hg}$ in the atmosphere and high $\mathrm{pH}$ of the paddy water and irrigation water, suggested that net production of $\mathrm{MeHg}$ at this site was limited. We propose that the concentration of $\mathrm{Hg}$ in am-
\end{abstract}

bient air is an indicator for the risk of $\mathrm{MeHg}$ accumulation in paddy rice.

\section{Introduction}

Reports of methylmercury ( $\mathrm{MeHg}$ ) contamination of rice grain (Oryza sativa) have recently focussed scientific attention on this important agricultural crop (Qiu et al., 2008; Zhang et al., 2010a; Meng et al., 2010, 2011, 2014). Numerous studies have reported high $\mathrm{MeHg}$ concentrations in rice grain collected from Indonesia (Krisnayanti et al., 2012) and different parts of China (Horvat et al., 2003; Qiu et al., 2008; M. Meng et al., 2014). The MeHg concentration in rice grain (brown rice) can be enhanced even in cases where soil is not significantly elevated in $\mathrm{Hg}$ (Zhang et al., 2010a; Horvat et al., 2003). Meng et al. (2014) specified that the majority $(\sim 80 \%$ ) of $\mathrm{MeHg}$ was found in edible white rice. A common theme in these studies is the presence of a high $\mathrm{Hg}$ flux into the environment through mining or other industrial contamination that discharges into the atmosphere.

Rice paddy plantation is one of the most prevalent land uses in south and east Asia, where rice is the dominant foodstuff (FAO, 2002). Rice throughout Asia is generally cultivated in paddy soil, and this ephemeral wetland is known to be an environment for $\mathrm{Hg}$ methylation. Current understanding is that the mobility and methylation of $\mathrm{Hg}$ in temporarily flooded soil is determined by a range of factors, such as redox potential, $\mathrm{pH}$, dissolved organic carbon, sulfur, iron, and 
dissolved Hg content (e.g., Ullrich et al., 2001; Benoit et al., 2001). Mercury methylation is largely facilitated by a subset of sulfate-reducing bacteria (SRB; Gilmour et al., 1992) and/or iron-reducing bacteria (Fleming et al., 2006) in anoxic conditions. Specially, the methylation of inorganic $\mathrm{Hg}(\mathrm{IHg})$ in paddy soil primarily occurs through a process mediated by sulfate-reducing bacteria (Peng et al., 2012; Rothenberg and Feng, 2012; Wang et al., 2014; Liu et al., 2009, 2014). $\mathrm{MeHg}$ accumulated throughout a rice plant during the growing season can be readily translocated to grain during riceseed ripening (Meng et al., 2011). Rice paddy fields have therefore been identified as important sources of $\mathrm{MeHg}$ in the terrestrial ecosystem (Meng et al., 2010, 2011) and a primary vector for human exposure to $\mathrm{MeHg}$ in $\mathrm{Hg}$ mining areas (Feng et al., 2008; Zhang et al., 2010b).

The general consensus among $\mathrm{Hg}$ researchers is that soil is the principal source of $\mathrm{MeHg}$ in rice plants, whereas $\mathrm{Hg}$ from the ambient air is the principal source of $\mathrm{IHg}$ in rice grain (Meng et al., 2010, 2011, 2012, 2014; Qiu et al., 2012; Yin et al., 2013). Recently, Meng et al. (2010, 2011) suggested that newly deposited $\mathrm{Hg}$ is more readily transformed to $\mathrm{MeHg}$ and accumulated in rice plants than $\mathrm{Hg}$ formed with an extended residence time in mining-contaminated soil. Meng et al. (2010) focused on the Wanshan area of China, a region of both historical large-scale and current small-scale mercury mining and showed that the $\mathrm{MeHg}$ concentration in rice grain collected from an active artisanal $\mathrm{Hg}$ mining areas $\left(32 \pm 14 \mathrm{ng} \mathrm{g}^{-1}\right)$ was significantly higher than in rice grain collected from an abandoned $\mathrm{Hg}$ mining area $\left(7.0 \pm 3.2 \mathrm{ng} \mathrm{g}^{-1}\right)$. Such studies on $\mathrm{MeHg}$ and rice emphasize that factors which control the biochemical cycling of $\mathrm{Hg}$ within rice paddy ecosystems are very complex and include the concentration and distribution of $\mathrm{Hg}$ in ambient air, wet and dry deposition, irrigation water, and the solid and liquid phases of soil. These factors in turn impact the absorption, transportation, and accumulation of $\mathrm{Hg}$ in rice plants (Meng et al., 2010, 2011, 2012, 2014; Rothenberg and Feng, 2012; Liu et al., 2012; Wang et al., 2014; Peng et al., 2012).

While the source, distribution, and accumulation of $\mathrm{IHg}$ and $\mathrm{MeHg}$ in rice plants has been reported, no study has presented results from a systematic survey of the concentration of $\mathrm{Hg}$ in the various physicochemical fractions of the rice paddy ecosystem. The biochemical processes that control the cycling of $\mathrm{Hg}$ in paddy soils impacted by $\mathrm{Hg}$ mining are poorly understood. The objectives of the current study were therefore to (1) investigate the speciation and distribution of $\mathrm{Hg}$ in paddy soil and (2) assess the primary source and mechanism for $\mathrm{Hg}$ methylation within a $\mathrm{Hg}$ mining area. Documenting $\mathrm{Hg}$ cycling in rice paddy ecosystems within $\mathrm{Hg}$ mining areas is an important step towards better assessing potential health threats that may be associated with rice cultivation in a Hg-contaminated environment and is necessary to mitigate the risk of $\mathrm{MeHg}$ formation in paddy soils used for rice cultivation in $\mathrm{Hg}$-contaminated areas. A better understanding of the distribution of $\mathrm{Hg}$ species in paddy soils

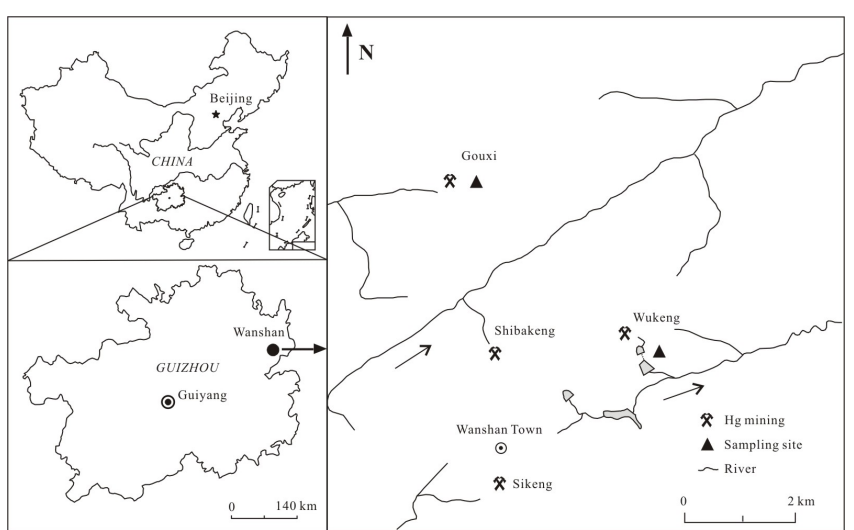

Figure 1. Map of the study area and sampling sites including abandoned $\mathrm{Hg}$ mining site (Wukeng) and artisanal $\mathrm{Hg}$ mining site (Gouxi).

within a $\mathrm{Hg}$ mining area is necessary to underpin more reliable risk assessment and appropriate strategies to remediate contaminated soil.

\section{Materials and methods}

\subsection{Site description}

This study was conducted in the Wanshan $\mathrm{Hg}$ mining district $\left(109^{\circ} 07^{\prime}-109^{\circ} 24^{\prime} \mathrm{E}, 27^{\circ} 24^{\prime}-27^{\circ} 38^{\prime} \mathrm{N}\right)$, Guizhou province, Southwest China, where historical large-scale $\mathrm{Hg}$ smelting combined with current artisanal $\mathrm{Hg}$ smelting activities have resulted in $\mathrm{Hg}$ contamination of ambient air, water, soil, sediment, and biota (Qiu et al., 2005; Li et al., 2008, 2009). Two typical Hg-contaminated sites within the Wanshan Hg mining district were selected for this study: an artisanal $\mathrm{Hg}$ mining site (Gouxi) and an abandoned Hg mining site (Wukeng; Fig. 1). The sampling sites of Gouxi and Wukeng are situated within the Wanshan district which experiences a subtropical monsoon-type climate with an average annual rainfall of $1200-1400 \mathrm{~mm} \mathrm{yr}^{-1}$ and a perennial mean temperature of $17^{\circ} \mathrm{C}$. Historical $\mathrm{Hg}$ mining activities in the Wanshan area can be dated back to the Qin Dynasty (221 BC) but large-scale mining activities officially ceased in 2001. Mining activity across Wanshan generated an estimated cumulative $1.0 \times 10^{8}$ tons of calcine and waste rock between 1949 and the 1990s. Recently, illegal artisanal Hg and small-scale mining activities have been revived due to an increase in the global $\mathrm{Hg}$ price and domestic demand.

The Gouxi artisanal $\mathrm{Hg}$ mining site is located to the north of Wanshan town (Fig. 1). Small-scale artisanal smelting was ongoing during the rice growing seasons of 2012 when the samples for the current study were collected. Mercury is released into the atmosphere during artisanal smelting and is subsequently deposited onto nearby rice paddy fields through wet and dry deposition. The Wukeng sampling site is located 
northeast of Wanshan town at an abandoned $\mathrm{Hg}$ mining area where large quantities of calcines were deposited along the river.

Paddy field is the primary agricultural land use at both Gouxi and Wukeng. Field sampling for the current research focused on two $10 \times 10 \mathrm{~m}$ plots (one at each site) within rice paddies that were established according to the following methodology: the rice paddies were flooded on 10 May; rice seedlings (hybrid rice) widely grown throughout Guizhou province were transplanted into the submerged soil 20 days after flooding (1 plant each $25 \times 25 \mathrm{~cm}$ area on 1 June, defined as Day 0). Thereafter, the two experimental plots were cultivated during the period 1 June through 10 September (100 days) 2012. Standing water $(2-8 \mathrm{~cm})$ was maintained above the soil surface (flooded condition) throughout the growing period, from Day 0 to Day 80 . The paddy fields were thereafter drained from Day 80, prior to harvest between Days 90 and 100. During the 10-day draining period, approximately $2-4 \mathrm{~cm}$ depth of water was maintained above the soil surface. The paddy plots received water through precipitation and stream water irrigation, while evaporation to air and seepage to the subsoil were the primary vectors for water loss. There was no direct runoff from either paddy.

\subsection{Sample collection and preparation}

Five consecutive sampling campaigns were conducted during the rice growing season (1 June-10 September 2012). The first sampling was initiated 20 days after the plants were planted out (20 June 2012; Day 20), and thereafter samples were collected on Days 40, 60, 80, and 100 (Day 100 was 10 September 2012; final harvest). The $\mathrm{Hg}$ concentration in ambient air was measured at each sampling time, and samples of cumulative deposition (wet and dry), irrigation water, paddy water, and soil cores were also collected each time. It should be noted that the current study focused on the speciation and distribution of $\mathrm{Hg}$ in the paddy soil during the rice growing season. Rice plant samples were not, however, collected as part of this study. The paddy fields were dry from Day 90, and therefore irrigation water, paddy water, and soil pore water samples were not collected on Day 100.

\subsubsection{Mercury in ambient air and wet and dry deposition}

The concentration of total gaseous mercury (TGM, $\mathrm{Hg}^{0}$ ) in ambient air at both Gouxi and Wukeng was measured in the field at each sampling time using an automated $\mathrm{Hg}$ vapor analyzer (LUMEX, RA-915 ${ }^{+}$, Ohio Lumex Co., Twinsburg, $\mathrm{OH})$ with a detection limit of $2 \mathrm{ng} \mathrm{m}^{-3}$. The average $\mathrm{Hg}^{0}$ concentration during a $10 \mathrm{~s}$ interval was quantified and stored in a portable computer. Measurements were carried out continuously for at least $1 \mathrm{~h}$. For each sampling interval 360 data points were collected at each location.
An integrated bulk precipitation sampler based on the design of Guo et al. (2008) was used in the field to quantify the concentration of $\mathrm{Hg}$ in cumulative precipitation (OSPAR Commission, 1998). Both dry and wet atmospheric deposition were collected concurrently with the TGM measurement once every 20 days using this sampling method. Samples collected at each site were poured into two $100 \mathrm{~mL}$ pre-cleaned borosilicate glass bottles for direct and unfiltered total $\mathrm{Hg}$ $\left(\mathrm{HgT}_{\text {unf }}\right)$ and total $\mathrm{MeHg}\left(\mathrm{MeHg}_{\text {unf }}\right)$ analysis. Filtered samples were collected on site using a $0.45 \mu \mathrm{m}$ disposable polycarbonate filter unit (Millipore) and subsequently analyzed for dissolved total $\mathrm{Hg}$ concentrations $\left(\mathrm{HgT}_{\mathrm{f}}\right)$ and dissolved $\mathrm{MeHg}$ concentrations $\left(\mathrm{MeHg}_{\mathrm{f}}\right)$

\subsubsection{Irrigation water and paddy water}

Samples of irrigation water at both Gouxi and Wukeng were collected at rice paddy inlets on Days 20, 40, 60, and 80. All water samples were collected by hand using ultra-clean handling protocols and stored in acid-cleaned borosilicate glass bottles. Each bottle was rinsed three times with irrigation water on site before sample collection. Filtered samples $\left(\mathrm{HgT}_{\mathrm{f}}-\right.$ dissolved total $\mathrm{Hg}$ concentration; $\mathrm{MeHg}_{\mathrm{f}}$ - dissolved $\mathrm{MeHg}$ concentrations) were collected on site through a $0.45 \mu \mathrm{m}$ disposable nitrocellulose filter unit (Millipore) for analysis. In addition, unfiltered irrigation water samples were siphoned into pre-cleaned borosilicate glass bottles using a disposable syringe and analyzed for total $\mathrm{Hg}\left(\mathrm{HgT}_{\text {unf }}\right)$ and total $\mathrm{MeHg}$ ( $\mathrm{MeHg}_{\text {unf }}$ ).

Paddy water (overlying water) and corresponding soil pore water samples at both Wukeng and Gouxi were collected at the center of the two plots on Days 20,40,60, and 80, simultaneously with the irrigation water collection. Firstly, an undisturbed soil core was collected at each sampling site by pushing a pre-cleaned $6 \mathrm{~cm}$ diameter polycarbonate core tube into the soil to approximately $20 \mathrm{~cm}$ depth. The paddy water ( $0-8 \mathrm{~cm}$ above the soil surface) in the core tube was siphoned into a $200 \mathrm{~mL}$ pre-cleaned borosilicate glass bottle. One aliquot of the paddy water was then filtered into a $100 \mathrm{~mL}$ pre-cleaned borosilicate glass bottle using a $0.45 \mu \mathrm{m}$ disposable polycarbonate filter unit (Millipore) and subsequently analyzed for $\mathrm{HgT}_{\mathrm{f}}$ and $\mathrm{MeHg}_{\mathrm{f}}$. A second aliquot of paddy water for $\mathrm{HgT}_{\text {unf }}$ and $\mathrm{MeHg}_{\text {unf }}$ analysis was immediately transferred into another $100 \mathrm{~mL}$ pre-cleaned borosilicate glass bottle.

General water quality characteristics of irrigation water and paddy water including $\mathrm{pH}$, dissolved oxygen (DO) concentration, and temperature $(T)$ were measured in situ using a portable analyzer. All water samples were promptly acidified on site to $0.5 \%(v / v)$ using adequate volumes of ultra-pure concentrated hydrochloric acid $(\mathrm{HCl})$. The sample bottles were then capped, sealed with Parafilm ${ }^{\circledR}$, doublebagged, and transported to the laboratory in an ice-cooled container within $24 \mathrm{~h}$. Prior to $\mathrm{Hg}$ analysis, samples were stored in a refrigerator at $+4^{\circ} \mathrm{C}$ in the dark. 


\subsubsection{Soil pore water (liquid phase) and soil core (liquid phase + solid phase)}

The soil cores were immediately sliced on site into $2 \mathrm{~cm}$ intervals using a plastic cutter in an oxygen-free glove box under argon. Firstly, the air (oxygen) in the glove bag was eliminated manually. Then, the pure argon from a portable argon tank was injected into the glove bag through Teflon tubing. The soil samples were placed in acid-cleaned $50 \mathrm{~mL}$ plastic centrifuge tubes, capped and sealed with Parafilm ${ }^{\circledR}$. All samples were transported in an ice-cooled container to the lab within $24 \mathrm{~h}$ and stored at $3-4{ }^{\circ} \mathrm{C}$ for further laboratory processing. Following centrifugation $\left(30 \mathrm{~min}, 3000 \mathrm{r} \mathrm{min}^{-1}\right.$, and $5^{\circ} \mathrm{C}$ ), the samples were returned to the glove box where the pore water was then filtered through $0.45 \mu \mathrm{m}$ disposable nitrocellulose filter unit (Millipore). The filtrate was stored in borosilicate glass bottles and divided for $\mathrm{HgT}_{\mathrm{f}}$ and $\mathrm{MeHg}_{\mathrm{f}}$ analysis. The water content of soil cores was estimated by weight loss.

At each sampling time (Days 0, 20, 40,60, and 80) a second soil core was collected and immediately placed into liquid nitrogen. This second set of soil cores was transported in a liquid nitrogen-iced container to the lab within $24 \mathrm{~h}$ and then sliced at $2 \mathrm{~cm}$ intervals. The sliced soil cores were then freeze-dried, prior to homogenization to 200 mesh with a mortar and pestle for analysis of total $\mathrm{Hg}(\mathrm{THg})$ and $\mathrm{MeHg}$. The concentration of each $\mathrm{Hg}$ species in this second set of soil cores is therefore the sum of both liquid and solid phase. Precautions were taken to avoid cross-contamination during sample processing; the mortar and pestle were thoroughly cleaned after each sample with drinking water followed by deionized water rinses. The powdered samples were subsequently packed into plastic dishes, sealed in polyethylene bags, and stored in a refrigerator in desiccators for subsequent laboratory analysis.

\subsection{Sample analysis}

All reagents used in this study were of guaranteed quality purchased from Shanghai Chemicals Co. (Shanghai, China).

\subsubsection{Total Hg and MeHg in soil samples}

For $\mathrm{THg}$ analysis, a soil sample $(0.1-0.2 \mathrm{~g})$ was digested using a fresh mixture of $\mathrm{HCl}$ and $\mathrm{HNO}_{3}(1: 3, v / v)$. THg was determined by cold vapor atomic fluorescence spectrometry (CVAFS; Tekran 2500, Tekran Instruments) preceded by $\mathrm{BrCl}$ oxidation, $\mathrm{SnCl}_{2}$ reduction, pre-concentration, and thermoreduction to $\mathrm{Hg}^{0}$ (US EPA, 2002).

For $\mathrm{MeHg}$ analysis, a soil sample $(0.3-0.4 \mathrm{~g})$ was prepared using the $\mathrm{CuSO}_{4}$-methanol-solvent extraction (Liang et al., 1996). MeHg in samples was extracted with methylene chloride, then back-extracted from the solvent phase into an aqueous ethyl phase. The ethyl analog of $\mathrm{MeHg}$, methylethyl $\mathrm{Hg}\left(\mathrm{CH}_{3} \mathrm{CH}_{3} \mathrm{CH}_{2} \mathrm{Hg}\right)$, was separated from the solution by purging with $\mathrm{N}_{2}$ onto a Tenax trap. The trapped $\mathrm{CH}_{3} \mathrm{CH}_{3} \mathrm{CH}_{2} \mathrm{Hg}$ was then thermally desorbed, separated from other $\mathrm{Hg}$ species by an isothermal gas chromatography (GC) column, decomposed to $\mathrm{Hg}^{0}$ in a pyrolytic decomposition column $\left(800^{\circ} \mathrm{C}\right)$, and analyzed by CVAFS (Brooks Rand Model III, Brooks Rand Labs, USA) following EPA method 1630 (US EPA, 2001).

\subsubsection{Total $\mathrm{Hg}$ and $\mathrm{MeHg}$ in water samples}

The analysis of $\mathrm{Hg}$ species in water samples was conducted within 3 weeks of sampling. The $\mathrm{HgT}_{\text {unf }}$ and $\mathrm{HgT}_{\mathrm{f}}$ concentration in water samples was quantified using dual amalgamation CVAFS (Tekran 2500, Tekran Inc., Toronto, Ontario, Canada) following an approved methodology (US EPA, 2002). Samples for $\mathrm{HgT}_{\text {unf }}$ and $\mathrm{HgT}_{\mathrm{f}}$ analysis were oxidized with $0.5 \%(v / v) \mathrm{BrCl}$ (bromine chloride). Excess $\mathrm{BrCl}$ was reduced with hydroxylammonium chloride before adding $\mathrm{SnCl}_{2}$ (stannous chloride) to convert $\mathrm{Hg}^{2+}$ to volatile $\mathrm{Hg}^{0}$. The $\mathrm{Hg}^{0}$ was trapped by gold amalgamation (US EPA, 2002). Water samples were analyzed for MeHg using CVAFS (Brooks Rand Model III, Brooks Rand Labs, Seattle, WA, USA) following distillation, aqueous phase ethylation, and isothermal GC separation (US EPA, 2001).

\subsection{Quality control}

Quantification for $\mathrm{THg}$ and $\mathrm{MeHg}$ in soil and water samples was conducted using daily calibration curves with the coefficient of variation $\left(r^{2}\right) \geq 0.99$. Quality control and assurance measurements for all analytes were performed using triplicates, method detection limits, field blanks, matrix spike recoveries, and certified reference materials. Field blanks of water samples were 0.12 and $0.011 \mathrm{ng} \mathrm{L}^{-1}$ for $\mathrm{THg}$ and $\mathrm{MeHg}$, respectively. The method detection limits $(3 \times \sigma)$ were 0.02 for THg and $0.002 \mu \mathrm{g} \mathrm{kg}^{-1}$ for $\mathrm{MeHg}$ in soil samples and 0.02 for THg and $0.01 \mathrm{ng} \mathrm{L}^{-1}$ for $\mathrm{MeHg}$ in water samples. The variability between the triplicate samples was less than $7.5 \%$ for $\mathrm{THg}$ and $\mathrm{MeHg}$ analysis for both water and soil samples. Recoveries for matrix spikes in water samples ranged from 88 to $108 \%$ for $\mathrm{THg}$ analysis and from 86 to $113 \%$ for $\mathrm{MeHg}$. The following certified reference materials were employed: Montana soil (SRM-2710, National Institute of Standards and Technology), Loamy Sand 1 (CRM024-050, Resource Technology Corporation), Sandy Loam 3 (CRM021-100, Resource Technology Corporation), and sediment (BCR-580, Institute for Reference Materials and Measurements). The results of the certified reference material analysis are shown in Table 1.

Statistical analysis was performed using the SPSS 13.0 software (SPSS). Mercury concentrations in samples are described by the analyzed mean \pm standard deviation (SD) unless otherwise stated. Relationships between covariant sets of data were subjected to regression analysis. Correlation coefficients $(r)$ and significance probabilities $(p)$ were computed 
Table 1. List of certified reference materials used in the present study and corresponding analytical result. CRM: certified reference material.

\begin{tabular}{llrlll}
\hline Producer & CRM & $n$ & Hg speciation & Obtained value & Certified value \\
\hline NIST & SRM-2710 & 10 & ${\mathrm{THg}\left(\mathrm{mg} \mathrm{kg}^{-1}\right)}^{-1}$ & $32.4 \pm 0.7$ & $32.6 \pm 1.8$ \\
RTC & CRM024-050 & 10 & $\mathrm{THg}\left(\mathrm{mg} \mathrm{kg}^{-1}\right)$ & $0.70 \pm 0.02$ & 0.71 \\
RTC & CRM021-100 & 10 & $\mathrm{THg}\left(\mathrm{mg} \mathrm{kg}^{-1}\right)$ & $4.73 \pm 0.15$ & 4.7 \\
IRMM $^{*}$ & BCR-580 & 20 & $\mathrm{MeHg}\left(\mathrm{mg} \mathrm{kg}^{-1}\right)$ & $0.070 \pm 0.007$ & $0.075 \pm 0.004$ \\
\hline
\end{tabular}

* IRMM: Institute for Reference Materials and Measurements. NIST: National Institute of Standards and Technology. RTC: Resource Technology Corporation.

for the linear regression fits. Differences are declared significant for $p<0.05$. Kolmogorov-Smirnov (K-S) and KruskalWallis $(\mathrm{K}-\mathrm{W})$ tests were carried out to compare the differences between two or more independent data sets (nonparametric tests).

\section{Results and discussion}

\subsection{Mercury in ambient air and precipitation}

The average TGM concentration in ambient air over the 100day rice season at Gouxi $\left(403 \pm 399 \mathrm{ng} \mathrm{m}^{-3}\right)$ was significantly higher than that at Wukeng $\left(28 \pm 13 \mathrm{ng} \mathrm{m}^{-3}\right)$ and the regional background $\left(6.2 \pm 3.0 \mathrm{ng} \mathrm{m}^{-3}\right.$; Table 2). Serious $\mathrm{Hg}$ contamination of air was therefore observed at Gouxi during the monitoring period. The elevated TGM concentration in ambient air at Gouxi compared to Wukeng and the regional background area (Huaxi) is attributed to the emission of gaseous $\mathrm{Hg}^{0}$ from nearby artisanal $\mathrm{Hg}$ smelters (Meng et al., 2010; Li et al., 2008, 2009).

During the rice growing season, the $\mathrm{HgT}_{\text {unf }}$ concentration in precipitation (wet and dry deposition) at Gouxi was elevated (mean: $2599 \pm 1874 \mathrm{ng} \mathrm{L}^{-1}$ ) and $1-3$ orders of magnitude higher than that recorded for Wukeng (mean: $445 \pm 296 \mathrm{ng} \mathrm{L}^{-1}$ ) and the regional background measured at Huaxi (mean: $27 \pm 17 \mathrm{ng} \mathrm{L}^{-1}$; Table 2). The relative concentration of $\mathrm{Hg}$ in precipitation between the three sites was comparable to the concentration of $\mathrm{Hg}$ in the ambient air suggesting that elevated $\mathrm{Hg}$ in precipitation at Gouxi can be linked to the ongoing $\mathrm{Hg}$ smelting activities. Mercury in precipitation is therefore a function of the enhanced flux of both dry and wet deposition of $\mathrm{Hg}$ from the atmosphere.

The $\mathrm{MeHg}_{\text {unf }}$ concentration in precipitation collected from the two sites (Gouxi: $0.48 \pm 0.20 \mathrm{ng} \mathrm{L}^{-1}$; Wukeng: $0.30 \pm 0.15 \mathrm{ng} \mathrm{L}^{-1}$ ) was similar to the regional background concentration of $\mathrm{MeHg}\left(0.28 \pm 0.14 \mathrm{ng} \mathrm{L}^{-1}\right.$; Table 2). Furthermore, there was no difference in $\mathrm{MeHg}_{\text {unf }}$ concentration between the two sampling sites during the rice growing season ( $\mathrm{K}-\mathrm{S}$ test, $p>0.05$ ). These results confirm previous suggestions that atmospheric deposition is responsible for the flux of inorganic $\mathrm{Hg}$ but not of $\mathrm{MeHg}$ to mining areas where artisanal $\mathrm{Hg}$ mining is ongoing (Meng et al., 2011).

\subsection{Mercury in irrigation water and paddy water}

The concentration of $\mathrm{Hg}$ in irrigation water and paddy water across the two sampling sites is presented in Table 3. Paddy fields selected in this study were irrigated with local stream water with a high concentration of $\mathrm{Hg}$ due to contamination of streams with calcines and tailings. During the rice growing season, irrigation water at Wukeng had a significantly higher $\operatorname{HgT}_{\text {unf }}\left(513 \pm 215 \mathrm{ng} \mathrm{L}^{-1}\right)$ and $\mathrm{MeHg}_{\text {unf }}\left(1.7 \pm 1.1 \mathrm{ngL}^{-1}\right)$ concentration than at Gouxi $\left(\mathrm{HgT}_{\text {unf }}=159 \pm 67 \mathrm{ng} \mathrm{L}^{-1} ; \mathrm{MeHg}_{\text {unf }}=0.75 \pm 0.65 \mathrm{ng} \mathrm{L}^{-1}\right)$. Mercury concentrations in irrigation water at both sites were significantly higher than the regional background $(p<0.05)$.

Clear differences were observed between the two sites with regard to $\mathrm{MeHg}$ concentration and the ratio of $\mathrm{MeHg}_{\text {unf }} / \mathrm{HgT}_{\text {unf }}$ in paddy water. The highest values of $\mathrm{MeHg}_{\text {unf }}$ in paddy water were all observed at Gouxi $\left(13 \pm 16 \mathrm{ng} \mathrm{L}^{-1}\right)$, whereas samples from Wukeng $\left(1.1 \pm 0.52 \mathrm{ng} \mathrm{L}^{-1}\right)$ maintained a relatively low $\mathrm{MeHg}$ concentration in paddy water throughout the rice growing season. The ratio of $\mathrm{MeHg}$ to total $\mathrm{Hg}$ is recognized as a measure of $\mathrm{Hg}$ methylation efficiency (Sunderland et al., 2006). In our study, the $\mathrm{MeHg}_{\text {unf }} / \mathrm{HgT}_{\text {unf }}$ ratio was up to $11 \%\left(\mathrm{MeHg}_{\text {unf }} / \mathrm{HgT}_{\text {unf }}\right)$ for paddy water at Gouxi and the mean ratio for this water compartment was significantly higher than for irrigation water $(0.71 \pm 0.93)$ and precipitation $(0.031 \pm 0.028$; Tables 2 and 3). However, there was no significant difference between the $\mathrm{MeHg}_{\text {unf }} / \mathrm{HgT}_{\text {unf }}$ ratios for the various water compartments at Wukeng (K$\mathrm{W}$ test, $p>0.05$ ). These results imply active net $\mathrm{Hg}$ methylation in paddy fields at Gouxi but not at Wukeng. The $\mathrm{MeHg}_{\text {unf }} / \mathrm{HgT}_{\text {unf }}$ ratios for precipitation $(0.76 \pm 0.41 \%)$, irrigation water $(2.2 \pm 0.98 \%)$, and paddy water $(10 \pm 7.9 \%)$ for both mining sites were elevated relative to the regional background, and we believe this is due to the lower $\mathrm{HgT}_{\mathrm{unf}}$ concentration reported for the regional background (Table 2).

\subsection{Mercury in soil profiles}

\subsection{1 $\mathrm{Hg}$ in soil pore water}

The vertical distribution of $\mathrm{HgT}_{\mathrm{f}}$ and $\mathrm{MeHg}_{\mathrm{f}}$ in pore water was monitored over four successive time intervals during the rice growing season (Fig. 2). The distribution of $\mathrm{HgT}_{\mathrm{f}}$ in 
Table 2. $\mathrm{Hg}$ in ambient air and precipitation at artisanal $\mathrm{Hg}$ mining site (Gouxi), abandoned $\mathrm{Hg}$ mining site (Wukeng), and regional background of Huaxi (mean $\pm \mathrm{SD})$.

\begin{tabular}{|c|c|c|c|c|c|c|}
\hline \multirow[b]{2}{*}{$\begin{array}{l}\text { Sampling } \\
\text { sites }\end{array}$} & \multirow{2}{*}{$\begin{array}{l}\text { Ambient air }{ }^{1} \\
\mathrm{Hg}^{0} \\
\left(\mathrm{ng} \mathrm{m}^{-3}\right)\end{array}$} & \multicolumn{5}{|c|}{ Precipitation $^{1}$} \\
\hline & & $\begin{array}{l}\mathrm{HgT}_{\text {unf }} \\
\left(\mathrm{ng} \mathrm{L}^{-1}\right)^{3}\end{array}$ & $\begin{array}{l}\operatorname{HgT}_{f} \\
\left(\operatorname{ng~L}^{-1}\right)^{3}\end{array}$ & $\begin{array}{l}\mathrm{MeHg}_{\text {unf }} \\
\left(\mathrm{ng} \mathrm{L}^{-1}\right)^{3}\end{array}$ & $\begin{array}{l}\mathrm{MeHg}_{\mathrm{f}} \\
\left(\mathrm{ng} \mathrm{L}^{-1}\right)^{3}\end{array}$ & $\begin{array}{l}\mathrm{MeHg}_{\text {unf }} / \mathrm{HgT}_{\text {unf }} \\
(\%)\end{array}$ \\
\hline Gouxi & $403 \pm 388$ & $2599 \pm 1874$ & $648 \pm 672$ & $0.48 \pm 0.20$ & $0.33 \pm 0.17$ & $0.031 \pm 0.028$ \\
\hline Wukeng & $28 \pm 13$ & $445 \pm 296$ & $164 \pm 166$ & $0.30 \pm 0.15$ & $0.14 \pm 0.07$ & $0.16 \pm 0.20$ \\
\hline Huaxi $^{2}$ & $6.2 \pm 3.0$ & $27 \pm 17$ & & $0.28 \pm 0.14$ & & $0.76 \pm 0.41$ \\
\hline
\end{tabular}

\footnotetext{
${ }^{1} \mathrm{Hg}$ species concentrations in ambient air and precipitation were averaged with data sets of five sampling campaigns at Days 20, 40, 60, 80, and 100. ${ }^{2}$ Data were obtained from Zheng (2007), Meng et al. (2010), and Meng (2011). ${ }^{3} \mathrm{HgT}_{\text {unf }}$, unfiltered total mercury; $\mathrm{HgT}_{\mathrm{f}}$, filtered total mercury; $\mathrm{MeHg}_{\text {unf }}$, unfiltered methylmercury; $\mathrm{MeHg}_{\mathrm{f}}$, filtered methylmercury.
}

Table 3. $\mathrm{Hg}$ irrigation water and paddy water at artisanal $\mathrm{Hg}$ mining site (Gouxi), abandoned $\mathrm{Hg}$ mining site (Wukeng), and regional background of Huaxi (mean $\pm \mathrm{SD})$.

\begin{tabular}{|c|c|c|c|c|c|c|c|c|c|c|}
\hline \multirow[b]{2}{*}{$\begin{array}{l}\text { Sampling } \\
\text { sites }\end{array}$} & \multicolumn{5}{|c|}{ Irrigation water ${ }^{1}$} & \multicolumn{5}{|c|}{ Paddy water ${ }^{1}$} \\
\hline & $\begin{array}{l}\mathrm{HgT}_{\text {unf }} \\
\left(\mathrm{ng} \mathrm{L}^{-1}\right)\end{array}$ & $\begin{array}{l}\mathrm{HgT}_{\mathrm{f}} \\
\left(\mathrm{ng} \mathrm{L}^{-1}\right)^{3}\end{array}$ & $\begin{array}{l}\mathrm{MeHg}_{\text {unf }} \\
\left(\mathrm{ng} \mathrm{L}^{-1}\right)\end{array}$ & $\begin{array}{l}\mathrm{MeHg}_{f} \\
\left(\mathrm{ng} \mathrm{L}^{-1}\right)^{3}\end{array}$ & $\begin{array}{l}\mathrm{MeHg}_{\mathrm{unf}} / \mathrm{HgT}_{\text {unf }} \\
(\%)\end{array}$ & $\begin{array}{l}\mathrm{HgT}_{\text {unf }} \\
\left(\operatorname{ng~L}^{-1}\right)\end{array}$ & $\begin{array}{l}\operatorname{HgT}_{\mathrm{f}} \\
\left(\operatorname{ng~L}^{-1}\right)\end{array}$ & $\begin{array}{l}\mathrm{MeHg}_{\text {unf }} \\
\left(\mathrm{ng} \mathrm{L}^{-1}\right)\end{array}$ & $\begin{array}{l}\mathrm{MeHg}_{\mathrm{f}} \\
\left(\mathrm{ng} \mathrm{L}^{-1}\right)\end{array}$ & $\begin{array}{l}\mathrm{MeHg}_{\text {unf }} / \mathrm{HgT}_{\text {unf }} \\
(\%)\end{array}$ \\
\hline Gouxi & $159 \pm 67$ & $39 \pm 9.4$ & $0.75 \pm 0.65$ & $0.31 \pm 0.30$ & $0.71 \pm 0.93$ & $189 \pm 117$ & $105 \pm 58$ & $13 \pm 16$ & $4.7 \pm 4.2$ & $5.9 \pm 4.4$ \\
\hline Wukeng & $513 \pm 215$ & $195 \pm 45$ & $1.7 \pm 1.1$ & $0.96 \pm 0.50$ & $0.45 \pm 0.53$ & $430 \pm 279$ & $196 \pm 78$ & $1.1 \pm 0.52$ & $0.62 \pm 0.29$ & $0.48 \pm 0.63$ \\
\hline Huaxi $^{2}$ & $7.1 \pm 4.0$ & - & $0.14 \pm 0.044$ & - & $2.2 \pm 0.98$ & $7.5 \pm 4.3$ & - & $0.71 \pm 0.66$ & - & $10 \pm 7.9$ \\
\hline
\end{tabular}

${ }^{1} \mathrm{Hg}$ species concentrations in irrigation water and paddy water were averaged with data sets of four sampling campaigns at Days 20, 40, 60, and 80. ${ }^{2}$ Data were obtained from Zheng (2007), Meng et al. (2010), and Meng (2011). ${ }^{3} \mathrm{HgT}_{\text {unf }}$, unfiltered total mercury; $\mathrm{HgT}_{\mathrm{f}}$, filtered total mercury; $\mathrm{MeHg}_{\text {unf }}$, unfiltered methylmercury; $\mathrm{MeHg}_{\mathrm{f}}$, filtered methylmercury.

pore water as a function of depth was different to that for $\mathrm{MeHg}_{\mathrm{f}}$ at both sampling sites. The mean $\mathrm{HgT}_{\mathrm{f}}$ concentration in pore water samples over the 100-day rice growing season was $142 \pm 111 \mathrm{ng} \mathrm{L}^{-1}$ (range: $15-460 \mathrm{ng} \mathrm{L}^{-1}$ ) at Gouxi and $180 \pm 160 \mathrm{ng} \mathrm{L}^{-1}$ (range: $38-916 \mathrm{ng} \mathrm{L}^{-1}$ ) at Wukeng. The highest concentration of $\mathrm{HgT}_{\mathrm{f}}$ in pore water was measured in the soil surface layer (top $2 \mathrm{~cm}$ ) and decreased with depth at both sampling sites. The $\mathrm{HgT}_{\mathrm{f}}$ concentration in pore water at Gouxi was relatively constant over time with no significant difference between the different sampling dates $(\mathrm{K}-\mathrm{W}$ test, $p>0.05)$. At Wukeng, the $\mathrm{HgT}_{\mathrm{f}}$ concentration in pore water was time-dependent, with the highest concentration in the surface layer recorded on Day 20 and the lowest on Day 80 (K-W test, $p<0.01)$.

The maximum concentration of $\mathrm{MeHg}_{\mathrm{f}}$ in soil pore water $\left(15 \mathrm{ng} \mathrm{L}^{-1}\right)$ was observed at Gouxi, and was approximately double that at Wukeng $\left(6.6 \mathrm{ng} \mathrm{L}^{-1}\right)$. The $\mathrm{MeHg}$ concentration in soil pore water collected at Gouxi was significantly higher than at Wukeng throughout the monitoring periods $(\mathrm{K}-\mathrm{S}$ test, $p<0.01)$, suggesting different rates of net $\mathrm{Hg}$ methylation between the Gouxi and Wukeng sites. The $\mathrm{MeHg}_{\mathrm{f}}$ concentration in pore water was generally highest in the surface soil at Gouxi, and then sharply declined from a depth of $4 \mathrm{~cm}$ onwards. In contrast, the vertical distributions of $\mathrm{MeHg}_{\mathrm{f}}$ in soil pore water of Wukeng showed little variation, with the exception of small (unexplained) peaks at $10 \mathrm{~cm}$ on Day 20 and at $6 \mathrm{~cm}$ on Day 60 . The proportion of pore water $\mathrm{HgT}_{\mathrm{f}}$ that was $\mathrm{MeHg}_{\mathrm{f}}\left(\mathrm{MeHg}_{\mathrm{f}} / \mathrm{HgT}_{\mathrm{f}}\right)$ ranged from 0.50 to $8.7 \%$ (mean value of $2.6 \pm 1.7 \%$ ) and from
0.089 to $4.8 \%$ (mean value of $1.6 \pm 1.1 \%$ ) at Gouxi and Wukeng, respectively. Regression analysis revealed a significant and positive correlation between $\mathrm{HgT}_{\mathrm{f}}$ and $\mathrm{MeHg}_{\mathrm{f}}$ at Gouxi $(r=0.75, p<0.001, n=40)$ but not at Wukeng ( $r=0.22, p=0.17, n=40$; Fig. 3), suggesting a mechanistic relationship between these two $\mathrm{Hg}$ species at the artisanal mining site only.

In order to better understand the factors controlling $\mathrm{Hg}$ methylation in rice paddy soil, the concentration of $\mathrm{Fe}^{2+}$, $\mathrm{Fe}^{3+}, \mathrm{S}^{2-}$, and $\mathrm{SO}_{4}^{2-}$ in soil pore water was determined and this data is described, in detail, in a related paper (Zhao et al., 2016). Briefly, no discernible vertical trend in $\mathrm{Fe}^{3+}$ distribution was observed in the soil pore water across the two sampling sites during the sampling period. The $\mathrm{Fe}^{2+}$ concentrations in soil pore water at Gouxi exhibited a narrow range $(41-417 \mu \mathrm{M})$, relative to that at Wukeng $(2.3-843 \mu \mathrm{M})$. The $\mathrm{S}^{2-}$ concentration in the soil pore water showed limited variation with depth at Wukeng (mean: $0.70 \pm 0.36 \mu \mathrm{M}$; range: $0.07-1.2 \mu \mathrm{M}$ ) relative to Gouxi (mean: $1.8 \pm 0.79 \mu \mathrm{M}$; range: $0.69-3.8 \mu \mathrm{M}$ ), with the highest value recorded in the surface soil layer at both sites. Temporal variation of sulfide concentrations at Wukeng and Gouxi was insignificant (K$\mathrm{W}$ test, $p=0.73$ and $p=0.33$ for Wukeng and Gouxi, respectively). The highest $\mathrm{SO}_{4}^{2-}$ concentrations were recorded in the surface soil layer and decreased with depth across the two sampling sites. As described in a related paper (Zhao et al., 2016), $\mathrm{SO}_{4}^{2-}$ stimulation of SRB activity was a potentially important metabolic pathway for $\mathrm{Hg}$ methylation in the rice paddy soil at the two $\mathrm{Hg}$ mining sites, while iron cycling 

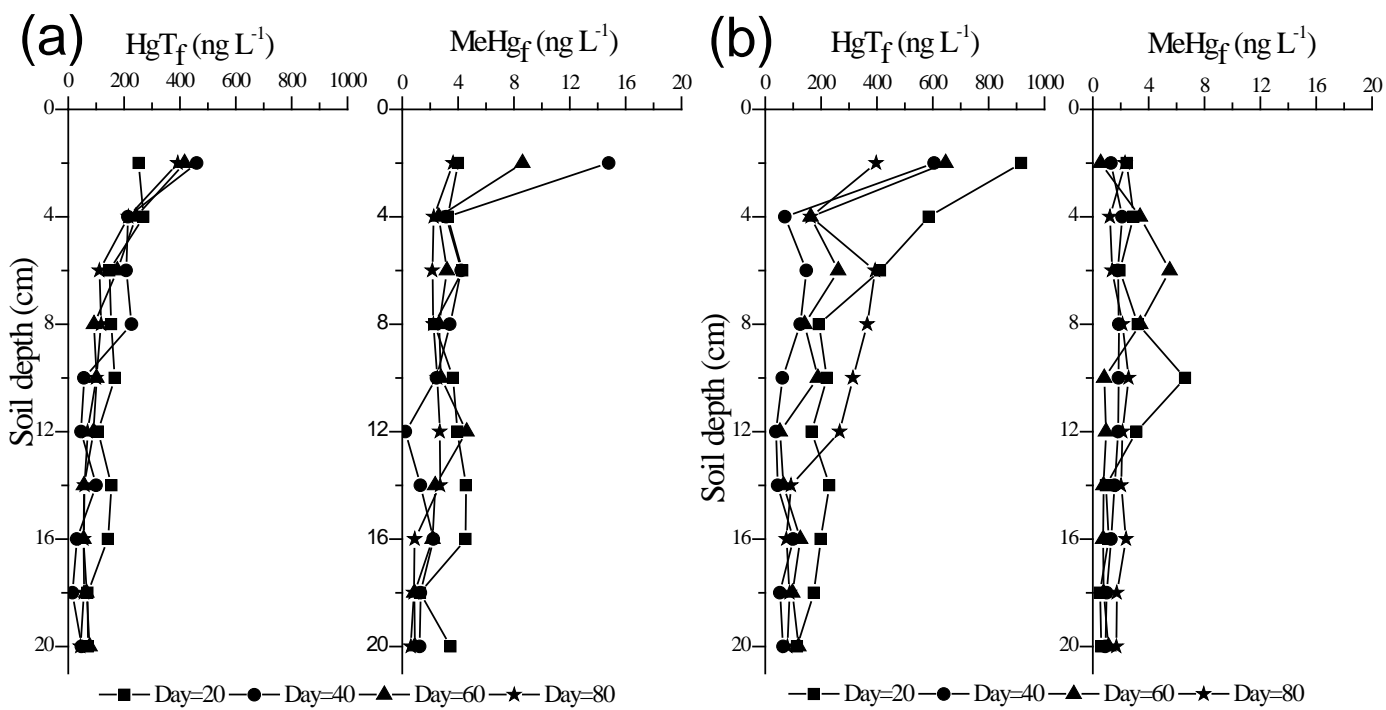

Figure 2. Concentration of $\mathrm{HgT}_{\mathrm{f}}$ and $\mathrm{MeHg}_{\mathrm{f}}\left(\mathrm{ng} \mathrm{L}^{-1}\right)$ in pore water during the rice growing season on Days 20, 40, 60, and 80: (a) artisanal $\mathrm{Hg}$ mining site of Gouxi; (b) abandoned $\mathrm{Hg}$ mining site of Wukeng.
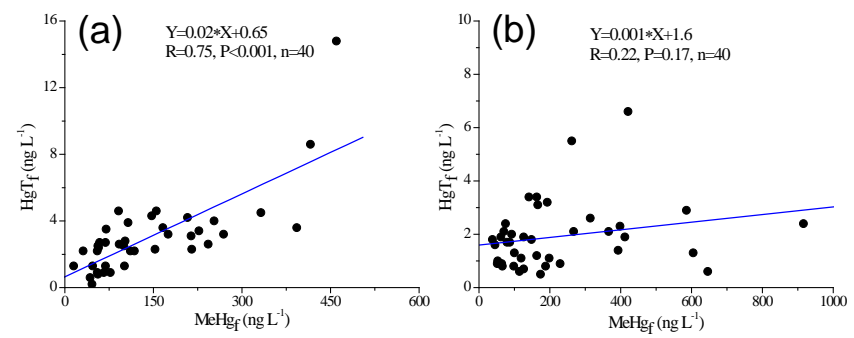

Figure 3. Correlation between $\mathrm{HgT}_{\mathrm{f}}$ and $\mathrm{MeHg}_{\mathrm{f}}$ concentrations in soil porewater during the rice growing season on Days 20,40,60, and 80: (a) artisanal $\mathrm{Hg}$ mining site of Gouxi; (b) abandoned $\mathrm{Hg}$ mining site of Wukeng.

in the rice paddies could impact the availability of $\mathrm{Hg}$ in pore water for methylation.

\subsubsection{Mercury in soil cores}

The concentration and distribution of $\mathrm{THg}$ as a function of depth in soil cores at Gouxi and Wukeng is shown in Fig. 4. Over the rice growing season, the mean concentration of THg in soil was $3.2 \pm 0.75 \mathrm{mg} \mathrm{kg}^{-1}\left(0.88-4.4 \mathrm{mg} \mathrm{kg}^{-1}\right)$ and $38 \pm 4.8 \mathrm{mg} \mathrm{kg}^{-1}\left(27-48 \mathrm{mg} \mathrm{kg}^{-1}\right)$ at Gouxi and Wukeng, respectively. The THg concentration in paddy soil collected from both Wukeng and Gouxi was higher than the domestic environmental quality standard for paddy fields in China $\left(0.5 \mathrm{mg} \mathrm{kg}^{-1}\right.$; GB15618-2008) and considered unsuitable for agricultural or residential use according to the level III criterion $\left(1.5 \mathrm{mg} \mathrm{kg}^{-1}\right)$ in the Chinese national standard for soil environmental quality. The $\mathrm{THg}$ concentration in soil cores showed no significant difference with depth although there was a nominal trend towards decreasing concentration at
Gouxi. For all depths the THg concentration in soil was elevated at Wukeng relative to Gouxi, reflecting a greater degree of historical contamination at Wukeng due to a long period of commercial mining activities.

In contrast to $\mathrm{THg}$, the $\mathrm{MeHg}$ concentration in soil cores showed significant variation with depth and time (Fig. 4). The MeHg concentration in soil cores at Gouxi showed a maximum value at the water-soil interface and decreased with depth on sampling Days 20 to 80. On Day 100, however, there was no increased $\mathrm{MeHg}$ concentration at the surface. The MeHg concentration in Wukeng soil cores showed very little variation with depth, and the $\mathrm{MeHg}$ concentration at this site, for all depths, was significantly lower than at Gouxi (K-S test, $p<0.001)$. Measured $\mathrm{MeHg}$ concentrations at the top of the Gouxi soil profile varied from $0.76 \mathrm{ng} \mathrm{g}^{-1}$ to $6.2 \mathrm{ng} \mathrm{g}^{-1}$ but remained relatively stable at Wukeng (range: $0.80-3.8 \mathrm{ng} \mathrm{g}^{-1}$ ). Comparison of the $\mathrm{MeHg}$ concentration and distribution patterns between the two sites supports the hypothesis of active Hg methylation in the Gouxi soil only.

Methylation can be affected by the $\mathrm{pH}$ and organic matter content of soil, and an analysis of soil physicochemical parameters in the soil cores of this study is reported in a related paper (Zhao et al., 2016). Briefly, the mean organic matter in soil cores was $4.8 \pm 0.75$ and $3.5 \pm 0.59 \%$ at Gouxi and Wukeng, respectively. The mean soil $\mathrm{pH}$ was the same for both sites $(6.7 \pm 0.10$ at Gouxi and $6.6 \pm 0.14$ at Wukeng) and did not change as a function of sampling time, despite the variation reported for irrigation water and paddy water at Wukeng in the current study (Table 4). The consistency of soil $\mathrm{pH}$ throughout the sampling period indicates that irrigation water and paddy water have little influence on bulk soil $\mathrm{pH}$. Statistical analysis revealed that there is no direct impact of $\mathrm{pH}$ and organic matter content on the $\mathrm{MeHg}$ concentration 
Table 4. Temperature (T), $\mathrm{pH}$, and dissolved oxygen (DO) in irrigation water and paddy water at the artisanal $\mathrm{Hg}$ mining site (Gouxi) and abandoned $\mathrm{Hg}$ mining site (Wukeng; mean $\pm \mathrm{SD}$, range).

\begin{tabular}{llll|lll}
\hline \multirow{2}{*}{$\begin{array}{l}\text { Sampling } \\
\text { sites }\end{array}$} & \multicolumn{3}{c|}{ Irrigation water } & \multicolumn{3}{c}{ Paddy water } \\
\cline { 2 - 7 } Gouxi & $T\left({ }^{\circ} \mathrm{C}\right)$ & $\mathrm{pH}$ & $\mathrm{DO}\left(\mathrm{mg} \mathrm{L}^{-1}\right)$ & $T\left({ }^{\circ} \mathrm{C}\right)$ & $\mathrm{pH}$ & $\mathrm{DO}\left(\mathrm{mg} \mathrm{L}^{-1}\right)$ \\
\hline \multirow{2}{*}{ Wukeng } & $24 \pm 1.7$ & $8.3 \pm 0.24$ & $7.4 \pm 0.43$ & $28 \pm 4.4$ & $7.2 \pm 0.24$ & $3.0 \pm 0.95$ \\
& $(23-26)$ & $(8.1-8.6)$ & $(6.9-8.0)$ & $(24-33)$ & $(6.9-7.4)$ & $(1.8-3.9)$ \\
& $25 \pm 2.1$ & $11 \pm 0.45$ & $7.4 \pm 0.56$ & $25 \pm 2.7$ & $8.6 \pm 1.3$ & $4.4 \pm 0.73$ \\
& $(23-27)$ & $(11-12)$ & $(6.8-8.1)$ & $(23-29)$ & $(7.3-9.8)$ & $(3.6-5.2)$ \\
\hline
\end{tabular}
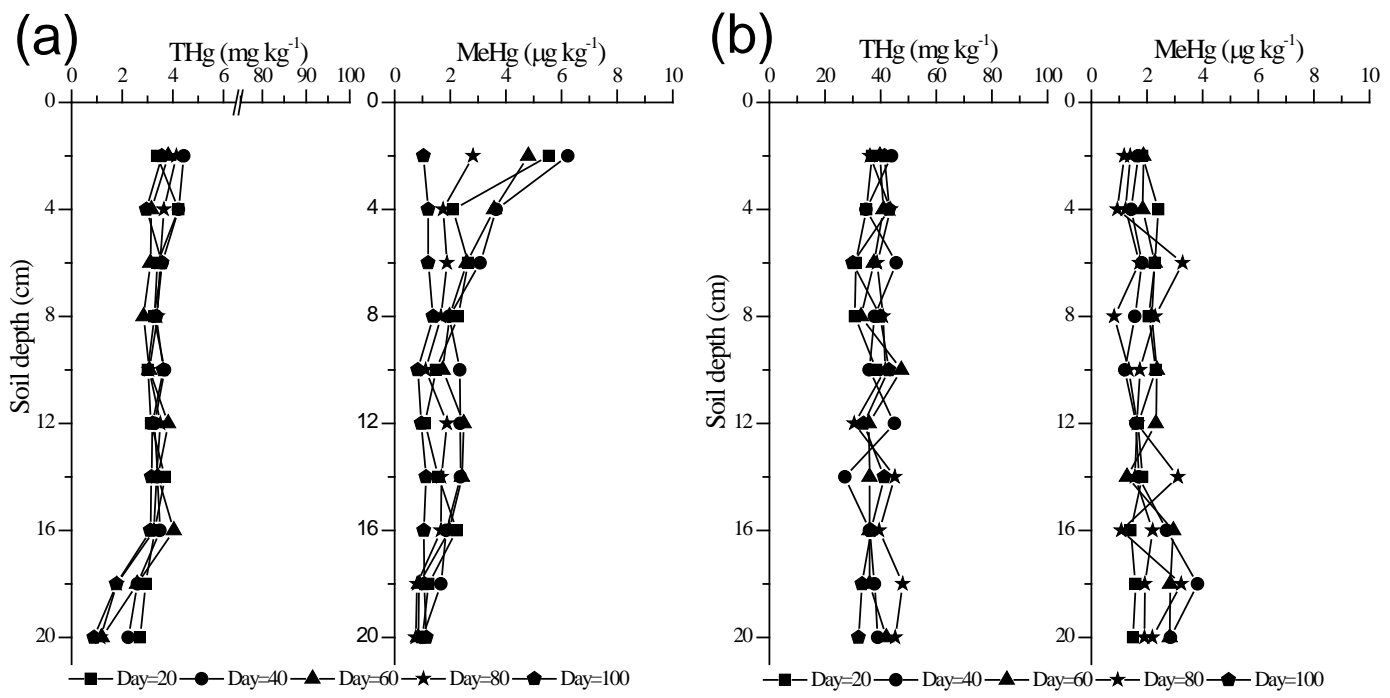

Figure 4. Concentration of $\mathrm{THg}$ and $\mathrm{MeHg}$ in soil cores during the rice growing season on Days 20, 40, 60, 80, and 100: (a) artisanal $\mathrm{Hg}$ mining site of Gouxi; (b) abandoned Hg mining site of Wukeng.

in soil across the two sampling sites, indicating that absolute $\mathrm{pH}$ and organic matter might not be the most important factors regulating $\mathrm{Hg}$ methylation activity (Zhao et al., 2016).

Changing redox parameters over the rice growing season may affect the process of $\mathrm{Hg}$ methylation. Previous studies have observed that in artificially $\mathrm{Hg}$-polluted soil, $\mathrm{Hg}$ bioavailability for methylation can be significantly affected by the level of water saturation (Rothenberg and Feng, 2012; Wang et al., 2014; Peng et al., 2012). Peng et al. (2012) specified that intermittent flooding, as opposed to continuous flooding, could reduce soluble $\mathrm{Hg}$ concentrations and inhibit $\mathrm{Hg}$ methylation in the rice rhizosphere, subsequently decreasing the accumulation of $\mathrm{MeHg}$ in rice grain. Flooded conditions enhance anaerobic microbial activities and increase MeHg yields. The drying of a paddy field is an important cultivation step to control rice plant tillering and increase yield. Therefore, one possible reason for the considerably elevated $\mathrm{MeHg}$ concentrations in soil at Gouxi between Day 20 and Day 80 relative to Day 100 is an enhancement of $\mathrm{Hg}$ bioavailability and the numbers of SRB under flooded conditions that stimulated $\mathrm{Hg}$ methylation, and increased the soil MeHg concentration (Wang et al., 2014). As the paddy field dried beginning on Day 80, some degree of net $\mathrm{MeHg}$ degradation may have occurred, which could be attributed to the decreased SRB numbers and proportion of $\mathrm{Hg}$ methylators in the rhizosphere under aerobic conditions (Wang et al., 2014). This could have contributed to a decreasing trend in soil $\mathrm{MeHg}$ concentration during the harvest period.

The profile of MeHg concentration with depth at Wukeng indicates limited $\mathrm{MeHg}$ production in this soil despite a significantly higher $\mathrm{THg}$ concentration when compared with Gouxi. The average concentration of THg in soil cores collected from Gouxi was 1 order of magnitude lower than that at Wukeng, whereas the $\mathrm{MeHg}$ concentration in soil cores at Gouxi was significantly higher than at Wukeng (K$\mathrm{S}$ test, $p<0.001)$ during the rice growing season. Further comparison reveals that the average $\mathrm{MeHg}$ concentration in the surface soil layer $(2 \mathrm{~cm})$ at Gouxi was approximately 3 times higher than that at Wukeng. To explain this apparent anomaly, differences in the source and pool of $\mathrm{Hg}$ at each site need to be considered. 


\subsection{Source and mechanism for $\mathrm{Hg}$ transformation in paddy field}

The mean concentration of $\mathrm{HgT}_{\mathrm{f}}$ in paddy water at Wukeng $\left(197 \pm 78 \mathrm{ng} \mathrm{L}^{-1}\right)$ was approximately 2 times higher than that at Gouxi $\left(105 \pm 58 \mathrm{ngL}^{-1}\right)$, whereas the $\mathrm{MeHg}_{\mathrm{f}}$ concentration in paddy water at Gouxi $\left(4.7 \pm 4.2 \mathrm{ng} \mathrm{L}^{-1}\right)$ was approximately 8 times higher than that at Wukeng $\left(0.62 \pm 0.29 \mathrm{ng} \mathrm{L}^{-1}\right.$; Table 3$)$. Furthermore, the concentration of $\mathrm{MeHg}_{\mathrm{f}}$ in paddy water at Wukeng $\left(0.62 \pm 0.29 \mathrm{ng} \mathrm{L}^{-1}\right)$ was significantly higher than that in precipitation $\left(0.14 \pm 0.07 \mathrm{ng} \mathrm{L}^{-1}\right)$ but significantly lower than in irrigation water $\left(0.96 \pm 0.50 \mathrm{ng} \mathrm{L}^{-1}\right)$ and soil pore water $\left(1.7 \pm 0.88 \mathrm{ng} \mathrm{L}^{-1}\right)$ in the soil surface layer during the rice growing season $(\mathrm{K}-\mathrm{S}$ test, $p,<0.00$; Table 2 and Table 3). Generally, there are three possible sources of MeHg in the paddy water: (1) in situ production, controlled by chemistry condition (e.g., redox and $\mathrm{pH}$ ), (2) diffusion of $\mathrm{MeHg}$ from underlying soil, and (3) MeHg flux of atmospheric deposition and irrigation. We propose that baseline $\mathrm{MeHg}_{\mathrm{f}}$ in paddy water at Wukeng is primarily due to the diffusion of $\mathrm{MeHg}$ from the surface layer of sediment and $\mathrm{MeHg}$ flux from atmospheric deposition and irrigation.

The sampling site for the Wukeng paddy was located next to a calcine pile and the proximity of this waste had a major impact on water chemistry. Both the irrigation water $(\mathrm{pH}$ : $11 \pm 0.45)$ and paddy water $(\mathrm{pH}: 8.6 \pm 1.3)$ were alkaline during the rice growing season (Table 4). We suggest that the alkaline conditions of the irrigation at Wukeng could restrain $\mathrm{Hg}$ methylation and/or stimulate $\mathrm{MeHg}$ demethylation in paddy water (Ullrich et al., 2001). Rothenberg et al. (2012) reported that alkaline paddy water $(\mathrm{pH}>11)$ at highly contaminated mining sites can restrain the bioavailability of $\mathrm{Hg}^{2+}$ for $\mathrm{Hg}$ methylation, resulting in lower pore water and soil $\mathrm{MeHg}$ concentrations despite higher total $\mathrm{Hg}$ concentrations. The findings of our study are in agreement with those of Rothenberg et al. (2012).

In contrast, the $\mathrm{MeHg}_{\mathrm{f}}$ concentration in paddy water at Gouxi $\left(4.7 \pm 4.2 \mathrm{ng} \mathrm{L}^{-1}\right)$ was significantly higher than in precipitation $\left(0.33 \pm 0.17 \mathrm{ng} \mathrm{L}^{-1}\right)$ and irrigation water $\left(0.31 \pm 0.30 \mathrm{ng} \mathrm{L}^{-1}\right)$ but significantly lower than in soil pore water $\left(7.8 \pm 5.2 \mathrm{ng} \mathrm{L}^{-1}\right)$ in the soil surface layer during the rice growing season ( $\mathrm{K}-\mathrm{S}$ test, $p<0.001$; Tables 2 and 3), with the data at Day 80 as an exception. The maximum $\mathrm{MeHg}_{\mathrm{f}}$ concentration was not recorded for the surface soil pore water $\left(3.6 \mathrm{ng} \mathrm{L}^{-1}\right)$ but for the paddy water $\left(4.7 \mathrm{ng} \mathrm{L}^{-1}\right)$ at Day 80. The implication is that $\mathrm{MeHg}$ in this region is not only due to $\mathrm{MeHg}$ diffusion from surface soil and/or the $\mathrm{MeHg}$ flux of atmospheric precipitation and irrigation but also from in situ methylation in anoxic water with relatively low pH (pH: 6.9 on Day 80; Table 4). Gilmour and Henry (1991) specified that low $\mathrm{pH}$ and anaerobic condition not only increase methylation rates but also decrease demethylation rates, resulting in net production of $\mathrm{MeHg}$. Both paddy water and irrigation water at Gouxi exhibit $\mathrm{pH}$ and redox conditions that can be considered optimal for $\mathrm{Hg}$ methylation (Table 4), favoring net methylation in the paddy water (Ullrich et al., 2001). Active $\mathrm{Hg}$ methylation within the Gouxi rice paddy is implied in the present study, even though data directly supporting this hypothesis are lacking. Further work may help to bring more confidence on that particular point.

During the rice growing season, $\mathrm{HgT}_{\text {unf }}$ in paddy water exceeded the EPA water-quality criterion of $50 \mathrm{ng} \mathrm{L}^{-1}$ (US EPA, 2000). No regulatory criterion for $\mathrm{MeHg}$ exists, but Rudd (1995) suggested that $\mathrm{MeHg}$ above a concentration of $0.1 \mathrm{ng} \mathrm{L}^{-1}$ is elevated and is likely to lead to significant $\mathrm{MeHg}$ bioaccumulation. During the rice growing season, photo demethylation can reduce paddy water $\mathrm{MeHg}$. However, the MeHg concentration in both filtered and unfiltered paddy water samples at both sites exceeded $0.1 \mathrm{ng} \mathrm{L}^{-1}$ (Table 3), confirming that rice paddies across the $\mathrm{Hg}$ mining area are an exposure pathway for $\mathrm{MeHg}$ and may have direct implications for human and wildlife health. Previous studies have indicated that vertebrates and fish cultivated in flooded rice paddies will accumulate $\mathrm{MeHg}$ to critical threshold levels within 30 days (Ackerman and Eagles-Smith, 2010; Ackerman et al., 2010). In rice paddy fields that combine rice and fish cultivation, potential co-exposure of $\mathrm{MeHg}$ through rice and fish consumption should receive more attention (Qiu et al., 2008; Feng et al., 2008; Lansing and Kremer, 2011).

Our finding that $\mathrm{MeHg}$ concentrations in surface soil at Gouxi were much higher than those at Wukeng indicate that newly deposited mercury can be expected to rapidly methylate after deposition. The peak concentration of $\mathrm{MeHg}$ in paddy soil at Gouxi was at the soil-water interface and decreased with depth. As concluded in a related paper (Zhao et al., 2016), absolute $\mathrm{pH}$ and organic matter might not be the most important factors regulating $\mathrm{Hg}$ methylation activity in rice paddy soil. Therefore, we believe that a restricted supply of newly deposited $\mathrm{Hg}$ to depths below the soil-water interface is a plausible explanation for the sharply reducing concentration of $\mathrm{MeHg}$ with depth at Gouxi; newly deposited $\mathrm{Hg}$ is constrained to surface soil and cannot be transferred to lower depth. Therefore, a direct positive relationship between $\mathrm{HgT}_{\mathrm{f}}$ and $\mathrm{MeHg}_{\mathrm{f}}$ concentrations in soil pore water was observed at Gouxi during the rice growing season (see Sect. 3.3.1).

The Wukeng site has received significant historic $\mathrm{Hg}$ deposition as a function of large-scale mining but is not currently receiving significant inputs of fresh $\mathrm{Hg}$. Atmospherederived mercury is physically unstable and bioavailable when it first enters the rice paddy (Hintelmann et al., 2002). Immediate reactions of this new $\mathrm{Hg}$ with soil constituents are governed by adsorption-desorption interactions with soil surfaces (Schuster, 1991), which favor the retention of $\mathrm{Hg}$ in the surface layers of the soil profile. Over time this newly deposited $\mathrm{Hg}$ will be transformed into more stable, less available forms (Schuster, 1991), and the net methylation potential of this $\mathrm{Hg}$ will consequently decrease. The relatively low 
$\mathrm{MeHg}$ concentration in soil at Wukeng is indicative of old $\mathrm{Hg}$ which has become tightly bound to soil complexes over time and is unavailable for methylation (Hintelmann et al., 2002). Consequently, there is no correlation between $\mathrm{HgT}_{\mathrm{f}}$ and $\mathrm{MeHg}_{\mathrm{f}}$ in soil pore water at Wukeng (see Sect. 3.3.1). Our data indicate that the THg concentration in soil is not a reliable indicator of $\mathrm{Hg}$ methylation potential in soil. Instead, the concentration of bioavailable or new $\mathrm{Hg}$ must be considered, in agreement with the findings of Meng et al. (2010, 2011).

\subsection{Implications of this work to environmental risk assessment}

Elevated $\mathrm{MeHg}$ concentrations combined with an elevated $\mathrm{MeHg}$ percentage in surface soil active $\mathrm{Hg}$ methylation processes are occurring in Gouxi rice paddy soil. The Hg methylation rate is a function of an elevated $\mathrm{Hg}$ concentration in the atmosphere. The absence of depth-dependent variability in the $\mathrm{MeHg}$ concentration in soil cores at Wukeng is consistent with the low concentration of $\mathrm{Hg}$ in ambient air and corresponding atmospheric deposition. The in situ production of $\mathrm{MeHg}$ in Wukeng soil, despite the elevated concentration of $\mathrm{THg}$, is low. Our results demonstrate that soil is the primary source of $\mathrm{MeHg}$ for paddy rice, and we believe that elevated $\mathrm{MeHg}$ in rice poses a potential threat to wildlife and local residents. Mercury in surface soil that has been derived from atmospheric deposition is susceptible to methylation in the rice paddy ecosystem immediately after deposition. Consequently, net $\mathrm{MeHg}$ production is principally governed by the supply of freshly deposited $\mathrm{Hg}$ to soil.

Because $\mathrm{MeHg}$ can be demethylated to $\mathrm{IHg}$ biotically and abiotically in soil or paddy water, rapid cycling occurs between the IHg and MeHg pools. The current study was limited to the rice growing season and not to the entire year or another period of time. Therefore, our results define the initial rather than long-term influence of newly deposited $\mathrm{Hg}$ on $\mathrm{MeHg}$ production. The overall contribution of old versus newly deposited $\mathrm{Hg}$ to the pool of $\mathrm{Hg}$ in paddy soil that is available for methylation will likely depend on the balance of $\mathrm{Hg}$ deposition and the rate at which this deposited $\mathrm{Hg}$ binds to soil constituents and on the magnitude of the IHg flux in the atmosphere. Our study provides no information on the extent to which the $\mathrm{MeHg}$ concentration in rice paddies will respond to $\mathrm{Hg}$ emission controls which seek to reduce the flux of atmospheric $\mathrm{Hg}$. The response of the paddy ecosystem to reductions in $\mathrm{Hg}$ emissions will depend on how long previously deposited $\mathrm{Hg}$ has been stored in paddy soil and on its availability to SRB. This issue is poorly understood, but previously reported declines in $\mathrm{Hg}$ loading suggest that $\mathrm{MeHg}$ levels in soil at abandoned $\mathrm{Hg}$ mining areas begin to respond within a few years of $\mathrm{Hg}$ reductions (Rothenberg et al., 2012). This provides hope that environmental risk mitigation strategies based on a more detailed understanding of the rice paddy ecosystem at mining-contaminated sites can be effectively enacted to protect human health.

The relationship between $\mathrm{MeHg}$ and freshly deposited $\mathrm{Hg}$ implies that the concentration of $\mathrm{Hg}$ in ambient air could be used as a monitoring tool to assess the relative risk of $\mathrm{MeHg}$ production in the rice paddy environment and the possible risk to human health that may be associated with the accumulation of this $\mathrm{MeHg}$ in rice grain. However, we cannot distinguish between newly deposited $\mathrm{Hg}$ and old $\mathrm{Hg}$ stored in paddy soil over decades, and ongoing research is necessary to continue to develop an improved understanding of $\mathrm{Hg}$ dynamics in rice paddy soils. When comparing relative risks between different vectors for $\mathrm{Hg}$ contamination (i.e., small-scale or historic large-scale mining), quantification of the pool of $\mathrm{Hg}$ available for methylation is critical to estimating reliable methylation rates. Ongoing work is urgently needed to further ascertain the relative importance of newly deposited $\mathrm{Hg}$ versus in situ $\mathrm{Hg}$ to the bioavailable pool of $\mathrm{Hg}$ that can be methylated in rice paddy ecosystems.

Acknowledgements. This research was financed by the National Key Basic Research Program of China (973 Program 2013CB430004), the National Natural Science Foundation of China (41173126, 41573135, 41203091, and 41473123), and the Natural Science Foundation of Guizhou (2012-2333).

Edited by: J. Kesselmeier

\section{References}

Ackerman, J. T. and Eagles-Smith, C. A.: Agricultural wetlands as potential hotspots for bioaccumulation: experimental evidence using caged fish, Environ. Sci. Technol., 44, 1451-1457, 2010.

Ackerman, J. T., Miles, A. K., and Eagles-Smith, C. A.: Invertebrate mercury bioaccumulation in permanent, seasonal, and flooded rice wetlands within California's Central Valley, Sci. Total Environ., 408, 666-671, 2010.

Benoit, J. M., Gilmour, C. C., and Mason, R. P.: The influence of sulfide on solid-phase mercury bioavailability for methylation by pure cultures of Desulfobulbus propionicus (1pr3), Environ. Sci. Technol., 35, 127-132, 2001.

FAO: Rice Information, Rome, Italy, 2002.

Feng, X. B., Li, P., Qiu, G. L., Wang, S. F., Li, G. H., Shang, L. H., Meng, B., Jiang, H. M., Bai, W. Y., Li, Z. G., and Fu, X. W.: Human exposure to methylmercury through rice intake in mercury mining areas, guizhou province, china, Environ. Sci. Technol., 42, 326-332, 2008.

Fleming, E. J., Mack, E. E., Green, P. G., and Nelson, D. C.: Mercury methylation from unexpected sources: Molybdate-inhibited freshwater sediments and an iron-reducing bacterium, Appl. Environ. Microbiol., 72, 457-464, 2006.

Gilmour, C. C. and Henry, E. A.: Mercury methylation in aquatic systems affected by acid deposition, Environ. Pollut., 71, 131$169,1991$. 
Gilmour, C. C., Henry, E. A., and Mitchell, R.: Sulfate stimulation of mercury methylation infresh-water sediments, Environ. Sci. Technol., 26, 2281-2287, 1992.

Guo, Y. N., Feng, X. B., Li, Z. G., He, T. R., Yan, H. Y., Meng, B., Zhang, J. F., and Qiu, G. L.: Distribution and wet deposition fluxes of total and methyl mercury in Wujiang River Basin, Guizhou, China, Atmos. Environ., 42, 7096-7103, 2008.

Hintelmann, H., Harris, R., Heyes, A., Hurley, J. P., Kelly, C. A., Krabbenhoft, D. P., Lindberg, S., Rudd, J. W. M., Scott, K. J., and St. Louris, V. L.: Reactivity and Mobility of New and Old Mercury Deposition in a Boreal Forest Ecosystem during the First Year of the METAALICUS Study, Environ. Sci. Technol., 36, 5034-5040, 2002.

Horvat, M., Nolde, N., Fajon, V., Jereb, V., Logar, M., Lojen, S., Jacimovic, R., Falnoga, I., Qu, L. Y., Faganeli, J., and Drobne, D.: Total mercury, methylmercury and selenium in mercury polluted areas in the province Guizhou, China, Sci. Total Environ., 304, 231-256, 2003.

Krisnayanti, B. D., Anderson, C. W. N., Utomo, W. H., Feng, X. B., Handayanto, E., Mudarisna, N., Ikram, H., and Khususiah.: Assessment of environmental mercury discharge at a four-yearold artisanal gold mining area on Lombok Island, Indonesia, J. Environ. Monitor., 14, 2598-2670, 2012.

Lansing, J. S. and Kremer, J. N.: Rice, fish, and the planet, P. Natl. Acad. Sci. USA, 108, 19841-19842, 2011.

Li, P., Feng, X.B., Shang, L. H., Qiu, G. L., Meng, B., Liang, P., and Zhang, H.: Mercury pollution from artisanal mercury mining in Tongren, Guizhou, China, Appl. Geochem., 23, 2055-2064, 2008.

Li, P., Feng, X. B., Qiu, G. L., Shang, L. H., Wang, S. F., and Meng, B.: Atmospheric mercury emission from artisanal mercury mining in Guizhou Province, Southwestern China, Atmos. Environ., 43, 2247-2251, 2009.

Liang, L., Horvat, M., Cernichiari, E., Gelein, B., and Balogh, S.: Simple solvent extraction technique for elimination of matrix interferences in the determination of methylmercury in environmental and biological samples by ethylation gas chromatography cold vapor atomic fluorescence spectrometry, Talanta, 43, 18831888, 1996.

Liu, J. L., Feng, X. B., Qiu, G. L.; Anderson, C. W. N., and Yao, H.: Prediction of Methyl Mercury Uptake by Rice Plants (Oryza sativa L.) Using the Diffusive Gradient in Thin Films Technique, Environ. Sci. Technol., 46, 11013-11020, 2012.

Liu, X. Z., Zhang, L. M., Prosser, J. I., and He, J. Z.: Abundance and community structure of sulphate reducing prokaryotes in a paddy soil of southern China under different fertilization regimes, Soil Biol. Biochem., 41, 687-694, 2009.

Liu, Y. R., Zheng, Y. M., Zhang, L. M., and He, J. Z.: Linkage between community diversity of sulfate-reducing microorganisms and methylmercury concentration in paddy soil, Environ. Sci. Pollut. Res., 21, 1339-1348, 2014.

Meng, B.: Biogeochemistry Process of Mercury in Sensitive Ecosystem and Health Risk Assessment, Southwest China, PhD Dissertation, The Graduate School of the Chinese Academy of Sciences, Beijing, China, 2011 (in Chinese with English abstract).

Meng, B., Feng, X. B., Qiu, G. L., Cai, Y., Wang, D. Y., Li, P., Shang, L. H., and Sommar, J.: Distribution patterns of inorganic mercury and methylmercury in tissues of rice (Oryza sativa L.) plants and possible bioaccumulation pathways, J. Agric. Food Chem., 58, 4951-4958, 2010.

Meng, B., Feng, X. B., Qiu G. L., Liang, P., Li, P., Chen, C. X., and Shang, L. H. The process of methylmercury accumulation in rice (Oryza sativa L.), Environ. Sci. Technol., 45, 2711-2717, 2011.

Meng, B., Feng, X. B., Qiu, G. L., Wang, D. Y., Liang, P., Li, P., and Shang, L. H.: Inorganic mercury accumulation in rice (Oryza sativa L.), Environ. Toxicol. Chem., 31, 2093-2098, 2012.

Meng, B., Feng, X. B.; Qiu, G. L., Anderson, C. W. N., Wang, J. X., and Zhao, L.: Localization and speciation of mercury in brown rice with implications for Pan-Asian public health, Environ. Sci Technol., 48, 7974-7981, 2014.

Meng, M., Li, B., Shao, J. J., Wang, T., He, B., Shi, J. B., Ye, Z. H., and Jiang, G. B.: Accumulation of total mercury and methylmercury in rice plants collected from different mining areas in China, Environ. Pollut., 184, 179-186, 2014.

OSPAR Commission: JAMP guidelines for the sampling and analysis of mercury in air and precipitation; Joint Assessment and Monitoring Programme, 1-20, 1998.

Peng, X. Y., Liu, F. J., Wang, W. X., and Ye, Z. H.: Reducing total mercury and methylmercury accumulation in rice grains through water management and deliberate selection of rice cultivars, Environ. Pollut., 162, 202-208, 2012.

Qiu, G. L., Feng, X. B., Wang, S. F., and Shang, L. H.: Mercury and methylmercury in riparian soil, sediments, mine-waste calcines, and moss from abandoned $\mathrm{Hg}$ mines in east Guizhou province, southwestern China, Appl. Geochem., 20, 627-638, 2005.

Qiu, G. L., Feng, X. B., Li, P., Wang, S. F., Li, G. H., Shang, L. H., and Fu, X. W.: Methylmercury accumulation in rice (Oryza sativa L.) grown at abandoned mercury mines in Guizhou, China, J. Agric. Food Chem., 56, 2465-2468, 2008.

Qiu, G. L., Feng, X. B., Meng, B., and Wang, X.: Methylmercury in rice (Oryza sativa L.) grown from the Xunyang $\mathrm{Hg}$ mining area, Shaanxi, Pure Appl. Chem., 84, 281-289, 2012.

Rothenberg, S. E. and Feng, X. B.: Mercury cycling in a flooded rice paddy, J. Geophys. Res., 117, G03003, doi:10.1029/2011JG001800, 2012.

Rothenberg, S. E., Feng, X. B., Zhou, W. J., Tu, M., Jin, B. W., and You, J. M.: Environment and genotype controls on mercury accumulation in rice (Oryza sativa L.) cultivated along a contamination gradient in Guizhou, China, Sci. Total Environ., 426, 272-280, 2012.

Rudd, J. W. M.: Source of methyl mercury to fresh-water ecosystems- a review, Water Air Soil Pollut., 80, 697-713, 1995.

Schuster, E.: The behavior of mercury in the soil with special emphasis on complexation and adsorption processes - A review of the literature, Water air soil pollut., 56, 667-680, 1991.

Sunderland, E. M., Gobas, F. A. P. C., Branfireun, B. A., and Heyes, A.: Environmental controls on the speciation and distribution of mercury in coastal sediments, Mar. Chem., 102, 111-123, 2006.

US EPA: Water quality standards - establishment of numeric criteria for priority toxic pollutants for the State of California, 40 CFR part 131, http://www.epa.gov/fedrgstr/EPA-WATER/2000/ May/Day-18/w11106.pdf (last access: 13 April 2015), 2000.

US EPA: Method 1630: Methylmercury in Water by Distillation, Aqueous Ethylation, Purge and Trap, and CVAFS, EPA-821-R01-020, Washington, DC, 2001. 
US EPA: Method 1631: Mercury in Water by Oxidation, Purge and Trap, and Cold Vapor Atomic Fluorescence Spectrometry (Revision E), EPA-821-R-02-019. Washington, DC, 2002.

Ullrich, S. M., Tanton, T. W., and Abdrashitova, S. A.: Mercury in the aquatic environment: A review of factors affecting methylation, Crit. Rev. Environ. Sci. Technol., 31, 241-293, 2001.

Wang, X., Ye, Z. H., Li, B., Huang, L. A., Meng, M., Shi, J. B., and Jiang, G. B.: Growing Rice Aerobically Markedly Decreases Mercury Accumulation by Reducing Both $\mathrm{Hg}$ Bioavailability and the Production of MeHg, Environ. Sci. Technol., 48, 18781885, 2014.

Yin, R. S., Feng, X. B., and Meng, B.: Stable Mercury Isotope Variation in Rice Plants (Oryza sativa L.) fromthe Wanshan Mercury Mining District, SW China, Environ. Sci. Technol., 47, 22382245, 2013.

Zhang, H., Feng, X. B., Larssen, T., Shang, L. H., and Li, P.: Bioaccumulation of methylmercury versus inorganic mercury in rice (Oryza sativa L.) grain, Environ. Sci. Technol., 44, 4499-4504, 2010a.
Zhang, H., Feng, X. B., Larssen, T., Qiu, G. L., and Vogt, R. D.: In inland China, rice, rather than fish is the major pathway for methylmercury exposure, Environ. Health Perspect., 118, 11831188, $2010 b$.

Zhao, L., Qiu, G. L., Anderson, C. W. N., Meng, B., Wang, D. Y., Shang, L. H., Yan, H. Y., and Feng, X. B.: Mercury methylation in rice paddies and its possible controlling factors in the $\mathrm{Hg}$ mining area, Guizhou Province, Southwest China, Environ. Pollut., under review, 2016.

Zheng, W.: Mercury Species in the urban air of Guiyang. Ph.D. Dissertation, The Graduate School of the Chinese Academy of Sciences, Beijing, China, 2007 (in Chinese with English abstract). 